\title{
A coastal foodscape: examining the relationship between changing fisheries and community food security on the west coast of Newfoundland
}

Kristen N. Lowitt $^{1}$

\begin{abstract}
Fisheries make vital contributions to food security and food security is an important part of fisheries governance. However, there are relatively few in-depth studies examining the consequences of collapsed and changing fisheries for the food security of coastal communities. In this case study I use the concept of the coastal foodscape to look at the relationship between changing fisheries and community food security in the Bonne Bay region on the west coast of Newfoundland. I examine the social-ecological interactions that compose the local food system and their changing relationship to community food security, and point to directions for developing a more resilient and democratic food system.
\end{abstract}

Key Words: community food security; fisheries restructuring; foodscapes

\section{INTRODUCTION}

Arising from a much longer history of studies of the landscape, recent years have seen a proliferation of "scape" studies across the social sciences and humanities. From relationscapes (Manning 2009) and bodyscapes (Geller 2009) to experiencescapes (O’Dell and Billing 2005), the idea of the scape has gained currency. According to Mikkelson (2011:210), a scape approach "can be helpful in understanding complex social systems in which humans, artifacts and environments interact." The idea of the scape has also been picked up in some recent writing about food systems. These studies have ranged from examinations of supermarket foodscapes (Johnston et al. 2009), to eating culture in urban foodscapes (Cummins and Macintyre 2002), to food celebrations in festive foodscapes (Adema 2009). In this paper I apply the idea of the foodscape to a coastal setting. Specifically, I apply the concept of the coastal foodscape to look at the relationship between fisheries restructuring and food security, focusing on the Bonne Bay region on the west coast of Newfoundland as a case study. The coastal foodscape concept aligns well with an understanding of fisheries as complex socialecological systems. Just as fisheries and the ocean are complex systems that involve humans as integral components of marine ecosystems (Ommer and Team 2007, Berkes 2011), so coastal foodscapes are complex social, cultural, and material entities. In this paper I use the coastal foodscape as a conceptual lens for examining interactions among people, food, and environments to better understand processes of fisheries restructuring in relation to food security. The coastal foodscape concept contributes both to the growing field of foodscape research, which has paid very little attention to coastal environments, and to research concerned with the rebuilding and governance of fisheries by connecting this field to the growing literature around community food security and local food systems.

Fisheries make vital contributions to food security directly as a source of food and indirectly through livelihood opportunities. Globally, fish provides nearly $20 \%$ of the protein intake for nearly three billion people and is an important protein source for people in many other countries (FAO 2012). About half of all the fish caught for human consumption comes from small-scale fisheries, underlying their importance for the world fish supply (FAO 2005).
These contributions have been recognized in the Food and Agriculture Organisation (FAO)'s Code of Conduct for Responsible Fisheries and the accompanying set of strategies for enhancing small-scale fisheries contributions to food security (FAO 2005). Striving for increased food security has become a key "good practice" for the governance of small-scale fisheries (Charles 2011).

In this context, a growing number of studies are looking at the linkages between fisheries and food security. However, these take very different approaches, ranging from those that consider fisheries primarily as production systems (Hilborn et al. 2012), to those looking at the vulnerability of fisheries to global environmental and economic change (McClanahan et al. 2013), to those considering fisheries as part of the place-based coastal food systems (Parrish et al. 2008, Moerlein and Carothers 2012, Hanazaki et al. 2013, Hauzer et al. 2013, Loring et al. 2013). This study is an important contribution to this latter group of studies by focusing on changing fisheries and the implications for community food security, including resiliency of the local food system, in the Bonne Bay region on the west coast of the island of Newfoundland.

I also use the theoretical construct, community food security, which places individual and household food security within a community context and explicitly recognizes the role of the larger food system in influencing food security outcomes (Dietitians of Canada 2007, Hamm and Bellows 2003, Winne 2005). Interest in community food security is part of a movement towards sustainable and local food systems in response to problems posed by the dominant industrial food system (Feagan 2007). Community food security literature emphasizes the interdependent social-ecological relationships that make up food systems and focuses on ways to build more local and resilient food systems for long-term food security (Hamm and Bellows 2003, Stroink and Nelson 2009, 2013, Levkoe and Wakefield 2011). Although the construct is most widely used in North American and European contexts, the aims of its proponents are similar to those of the food sovereignty movement in developing countries within which farmers and fishers are seeking to reclaim local control over food systems and livelihoods (Wittman et al. 2010). 
Community food security is a particularly important construct for fisheries research in which concerns about the interlinked social and ecological components of marine ecosystems and the impacts of changing fisheries for household and community resilience, as is typical of contexts where fish stocks have collapsed (Khan and Neis 2010), are a central concern (Marshall and Marshall 2007, Ommer and Team 2007, Coulthard 2012, Hanazaki et al. 2013). As Eriksen (2008) argues, much of the food security literature remains conceptually limited in terms both of understanding food as a component of social-ecological systems and assessing their resilience to change. If it is to be more useful, however, the community food security literature requires more fully developed analytical approaches (Anderson and Cook 1999, Carlsson and Williams 2008). For example, as the field continues to grow, more consideration needs to be paid to how "community" and the "local" are defined as units of analysis (Hinrichs 2003, Carlsson and Williams 2008). Furthermore, many community food security studies remain focused on a particular segment of the food system, such as production or consumption. Therefore, I propose the foodscape as a new conceptual lens for understanding community food security that helps address some of these criticisms.

\section{The foodscape: a new lens for understanding fisheries restructuring and community food security}

Because the landscape is an array of related features, so the foodscape is a spatial array of "the actual physical sites where we find food" (Friedberg 2010:1868). However, like landscapes, foodscapes are social as well as material (Mitchell 2001). Adema (2009:5) described them as "a marriage between food and landscape, both the conceptual notion (idea) of landscape and actual, physical landscapes." Thus foodscapes consist of the physical places in which food can be obtained as well as the meanings and relationships with food that emerge in these settings. However, beyond this general understanding, there is no one definition of what a "foodscape" is, nor is there a fully developed theoretical framework for guiding foodscape research (Mikkelsen 2011). In this respect, it is useful to turn to Appadurai's (1990) pathbreaking work on global cultural flows in terms of different types of scapes, including ethnoscapes, mediascapes, technoscapes, financescapes, and ideoscapes. This work has been instrumental in promoting an understanding of scapes as "fluid, irregular" and "shifting" (Appadurai 1990:297). Because of this, scapes do not look the same from every angle, but rather are "deeply perspectival constructs, inflected very much by the ... situatedness of different sorts of actors" (Appadurai 1990:296). Appadurai (1990:296) additionally notes that scapes are "navigated by agents who both experience and constitute larger formations." Thus the interconnectedness of scapes is one of their basic features.

With the refinements noted above, coupled with an awareness that foodscapes are not always land-based, but can also incorporate marine and freshwater bases, foodscape analyses can be used to help understand the changing social-ecological interactions that make up food systems. This understanding, in turn, may contribute to devising better mechanisms for promoting community food security, including more local and resilient food systems. In this way, the foodscape approach can complement other kinds of analyses including those on foodsheds, which have been used to understand human relationships with food in particular localities (Kloppenburg et al. 1996), as in Loring and Gerlach's (2009) examination of changes taking place in rural Alaska's fisheries and land-based foodscapes. A strength of the coastal foodscape construct, as refined here, is that it has a perspectival dimension and, as such, is particularly amenable to revealing the range of perspectives that exist in particular contexts related to the "local" and "community." It can also help us think about discourses and food sites across multiple scales.

\section{CASE STUDY}

\section{The Bonne Bay region}

Bonne Bay is the case study for this coastal foodscape study. Bonne Bay is a fjord located in Gros Morne National Park, a designated UNESCO world heritage site situated on Newfoundland's west coast (see Fig. 1). There are five communities located along the north and south sides of Bonne Bay: Rocky Harbour and Norris Point on the north side and Woody Point, Glenburnie/Birchy Head/Shoal Brook, and Trout River on the south with a total population of about 3000 people. Gros Morne National Park was established in 1972. Since then, with the exception of Trout River, which is located just beyond the Park boundary, these communities have been surrounded by the park. A large number of tourists visit the region each year.

Fig. 1. Map of the Bonne Bay region (Lowett 2012).

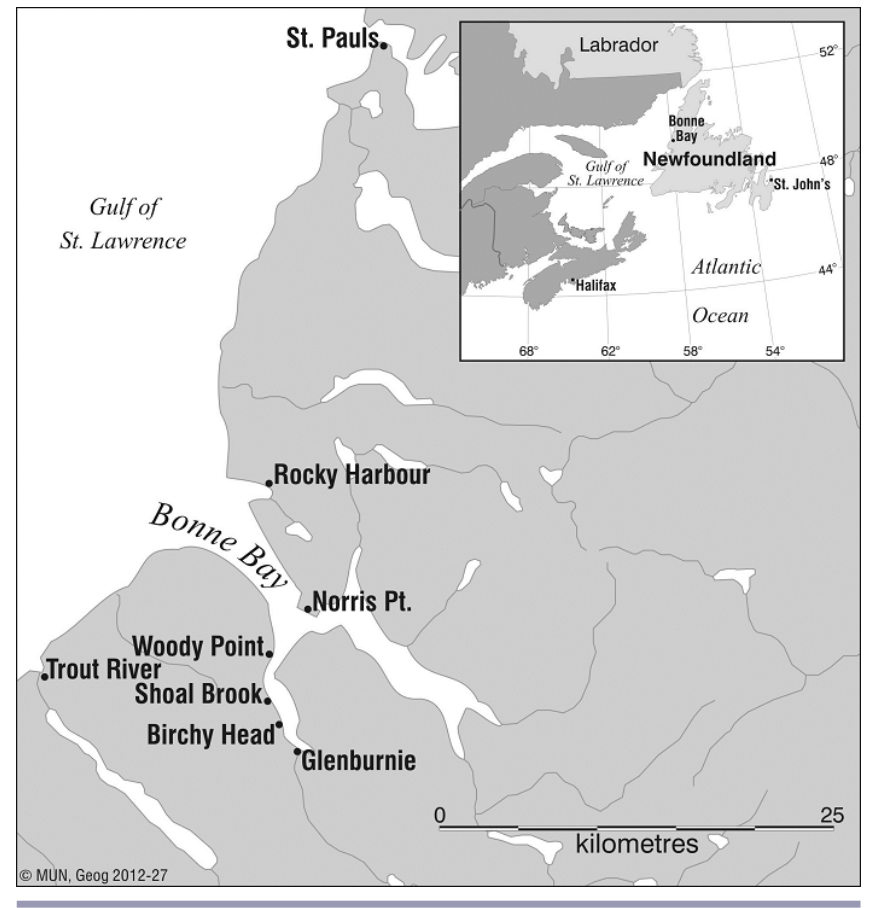

Early settlement around Bonne Bay, as on some other parts of the west coast, was linked to a combination of opportunities in fishing and forestry (Mannion 1977). One of the first fish species to be caught commercially along this part of the west coast was salmon, and it remained the main commercial commodity for the first part of the 19th century (Mannion 1977). The permanent population around Bonne Bay remained fairly small until the 1860 s when the region began attracting immigrants linked to a growing herring fishery. After 1860, herring became the main 
commercial staple for Bonne Bay, Bay of Islands, and Bay St. George to the south (Mannion 1977). In the 1850s, a commercial trade had also begun in lobster, while the cod fishery served as an "adjunct" to these other fisheries (Mannion 1977:266). After 1870 , however, the cod fishery grew with the introduction of larger vessels and the subsequent extension of the fishery north to Labrador in response to declining cod stocks in the older east coast fishing areas. Many families around Bonne Bay participated in an annual seasonal migration to the Labrador coast to fish for cod.

In addition to fishing resources, subsistence agricultural production was important, while an abundance of fuel in the Bay, combined with the possibility of winter employment in logging, were also draws for settlers (Mannion 1977) so that, by the beginning of the 20th century, there were over 1600 residents in Bonne Bay. Throughout much of the 20th century residents continued to practice this kind of occupational pluralism to make a living. As elaborated in Lowitt (2012), traditional foodways were based on a seasonal round of food provisioning that combined gardening, hunting, and fishing for sale and subsistence. Households provided for themselves as much food as they could to depend less on credit from the merchant store (Ommer et al. 2007). One interview informant who grew up in Bonne Bay in the 1930s described the importance of salt fish to their diet: "Oh we ate a lot of fish. But mostly it was salt fish. In the winter we had salt fish because there was no electricity. Everything we ate in the winter was salted."

More substantial change to traditional foodways and fishing activities came in the 1950s with more modern goods, services, and money coming in to the province following its confederation with Canada (Omohundro 1994, Hanrahan 2002). Unpaid processing of fish by women, men, and children in household enterprises shifted to paid wage labor in largely fresh fish processing plants. Instead of credit at the merchant store cash was increasingly paid directly to fish harvesters for their catches and prices for goods were less defined by the merchant credit system. Imported foods likewise became more accessible (Omohundro 1994).

Present-day change in many coastal communities across the island, including in the Bonne Bay region, has been particularly rapid since the collapse of cod and other groundfish stocks in the early 1990s across eastern Canada. At that time, all cod and other groundfish fisheries in Newfoundland and Labrador were placed under temporary moratoria. In the Bonne Bay region two moratoria were imposed on northern gulf cod between 1994 and 1996 and again in 2003 (FRCC 2011). Alongside the cod moratoria, declining abundance of Atlantic salmon (Salmo salar) coupled with effective lobbying by recreational salmon fishing organizations led to a commercial salmon fishing moratorium across the island in 1992, and the commercial fishery has not reopened since (Fisheries and Oceans Canada 1997, Chase 2003).

Today, the main economic activities in the Bonne Bay region are fishing and tourism, both of which are highly seasonal. Tourism has assumed an important role with the advent of the national park and also partly in response to the substantial downsizing that has taken place in fisheries employment in the region and related state support for this sector over the past 20 years. Nonetheless, fishing remains an important industry, with about
$17 \%$ of the workforce in Bonne Bay employed in the industry in 2005, including 195 people in fish harvesting and 70 in fish processing (Newfoundland and Labrador Statistics Agency 2009). Since the early 1990s, demographic changes in Bonne Bay are similar to those seen in other rural parts of the province, including a high rate of out-migration, particularly among young people (MacDonald et al. 2013).

\section{METHODS}

It is in this context of rapid social and economic change that this study examines the coastal foodscape around Bonne Bay today, including the contribution of fisheries to the local food system. The study uses mixed methods including a household survey about seafood consumption, interviews with households about their food provisioning practices, and participant observation with fish harvesters and tourism operators.

An anonymous survey $(\mathrm{n}=307)$ was administered to all households in the Bonne Bay region to collect information about seafood consumption, including frequency and types of seafood consumed, sources for obtaining seafood, and ways of eating seafood (see Lowitt 2013 for details). Following the survey, semistructured interviews were completed with households in the region $(n=37)$ about their food provisioning practices, focusing on what the household eats in a typical week and where it comes from, including purchased and self-provisioned sources. An additional set of questions was asked specifically about seafood consumption. Maximum variation sampling was used to purposively select households to meet a range of characteristics and thus increase the range of data uncovered by the study (Kuzel 1992).

Last, participant observation was undertaken with four fish harvesters and four tourism operators in the region with the purpose of understanding local fish supply, markets, and potential synergies among the fisheries and tourism sectors. As an overt participant-observer, I observed the setting and engaged in activities. To broaden the relevance of the findings beyond lessons learned from the participant observation, a small set of key informant interviews were carried out with other key stakeholders in the fishing and tourism industries.

\section{RESULTS AND DISCUSSION}

Although traditional foodways in Bonne Bay were based on a combination of gardening, hunting, and fishing, this discussion focuses on fisheries as a vital part of the region's settlement and food systems. I use the coastal foodscape as an organizing framework for tracing the social-ecological interactions shaping fisheries contributions to community food security in the Bonne Bay region over time. The discussion concludes by situating fisheries within the broader coastal foodscape, including landbased food resources that may contribute to community food security in Bonne Bay.

Although fisheries in Bonne Bay continue to undergo change, they remain important to community food security through contributions to local livelihoods, diets, and culture. There are a number of active commercial and recreational (subsistence) fisheries in the region, including commercial fisheries for crab, lobster, cod, mackerel, halibut, herring, capelin, shrimp, and turbot (Scophthalmusmaximus) and recreational fisheries for cod, trout, smelt, and salmon. The main market for fish harvesters is 
local fish processing plants. Selling to a fish processor or a licensed buyer allows harvesters to qualify for employment insurance earnings in the offseason. The majority of the catches purchased by fish plants are exported, although most sell some seafood locally to residents, tourists, and restaurants. Approximately 50\% of surveyed households ranked local fish plants as their main source of local seafood. However, many fish harvesters also undertake direct sales to capture more value for some of their catch. Technically under the provincial Fish Inspection Act (Government of Newfoundland and Labrador 1990), a person may not purchase fish from a harvester without a fish buyer's license or a fish processing license. As such, this Act prohibits direct sales of seafood from fish harvesters to local people, tourists, or restaurant owners who lack these licenses (Khan 2011, Murphy and Neis 2011). Nonetheless, many households purchase some seafood directly from fish harvesters through informal economic networks. Surveyed households ranked friends and family, including informal purchases from fish harvesters, as the second most important source for local seafood following local fish plants.

A preference among households for eating local over imported seafood attests to the importance of these fisheries to local diets. As described in Lowitt (2013), survey results show households eat local (from Newfoundland and Labrador) seafood more often than nonlocal seafood, and, unlike nonlocal seafood, which is eaten by the majority of household less than once a week throughout the year, the frequency of local seafood consumption changes with the seasons. Specifically, local seafood is eaten most frequently in the summer, the season for most commercial and recreational fisheries, and the least in the winter. For example, as one interviewee Nancy (pseudonym) described: "In the summer we might have it two or three times a week when it's readily available, right from the water to the frying pan basically. I still try, if not once a week, once a week and a half I try to get a fish dish in [in the winter]." In interviews, many households said they prefer local seafood because it tastes better, is fresher, they know who caught it, and they can support local fish harvesters.

These present-day food practices arise out of a much longer social and cultural history tied to fishing. As Ingold (1993) argued, an integral feature of landscapes, and other types of scapes, is their temporality. For example, some people fish in particular grounds because of ties to family history and identity. Ernie Decker has fished for nearly 40 years out of Baker's Brook, the same place from which his father fished before him and from which his brother also presently fishes. Lynn Halfyard, who was a crewmember with Ernie's enterprise said: "When you're fishing so long in a certain area you know your ground."

The consumption of seafood is likewise shaped by patterns of food use that have developed over generations. Codfish has long been a staple in the diet, and was ranked by surveyed households as the most frequently eaten and favorite type of seafood today. Further, $70 \%$ of surveyed households salt codfish to preserve it for the winter (Lowitt 2013). Salting was a traditional practice to keep fish for the winter months before refrigeration was available. Salting is a skilled activity and interview findings suggest that households continue to salt fish because they value traditional foodways. However, as new fisheries have developed, some types of seafood have been more recently introduced to diets. For example, snow crab is a relatively new fishery, beginning in the late 1960s (and more recently in this region) and growing substantially since then (Rose 2003). Interviewee Aleck described a change in diet accompanying the rise of this fishery. Although he presently fishes crab and keeps some for his family's consumption, he explained that when his father was fishing he would release crab back in the water because "no one knew how to cook it."

Accessing local seafood is also often based on social relations with fish harvesters that build on a long community history of exchange in the coastal foodscape. For example, Billy explained how his family obtained seafood: "[We've] never bought a dried [cod] fish. If we can't get it from the food fishery we get it from fishermen." Mary similarly said, "I know the fishermen, a couple of them are friends, I basically know where to go. I know who's going to give me top-quality, skinned fillets, dried. I can put in an order for fillets fresh or dried."

Thus fishing, food, and place are deeply intertwined within the temporality of the coastal foodscape around Bonne Bay. However, within this coastal foodscape, the situatedness of different actors contributes to different meanings surrounding "local" seafood and fisheries. For example, Deatra and Cathy both live in the same town. Cathy's husband works in fishing and she obtains most of her family's seafood from her husband's catches, whereas no one in Deatra's immediate family is currently fishing. Deatra described the seafood she purchased at fish plants as "from local people somewhere." In contrast, Cathy, when asked if there was any seafood she couldn't get in her community said, we "have to travel in the boat 15 to 20 minutes for mussels at Shoal Point." Cathy may well, then, have a different understanding than Deatra of what constitutes "local" seafood, because she constructs her understanding in relation to her husband's fishing grounds. From another perspective, Kyle recently moved to the region and continues to obtain fish from his Dad on the east coast of the Island. He said, "So it's [fish] not local, it's local from the east coast. Locally caught. I mean caught by a family member in Newfoundland waters, that kind of local." For Kyle, a history of eating fish caught by his Dad contributes to it being "local," even though it is less geographically proximate to him than fish caught in Bonne Bay. The relational and temporal aspects of place have received less attention in community food security research, which tends to focus on the local mostly in terms of geographical proximity (Allen 2010). However, being attentive to the constructed nature of the local may enable better understanding of the social and ecological particularities shaping everyday interactions in foodscapes (Feagan 2007).

In this study I provide evidence that local fisheries remain important to community food security in Bonne Bay today, and these contributions are embedded in a much longer socialecological history. However, there are also indications that households face increasing difficulty in accessing local seafood and that fishing families are dealing with growing livelihood challenges. First, as detailed in Lowitt (2013), there is evidence from the survey that consumption of local seafood is declining. The survey asked households to indicate how frequently they ate 15 different types of local seafood over a five-year time period (2006-2011). Although the extent of decline varied according to species, results show how often households ate most types of local 
seafood decreased over this five-year time period. Although there is a possibility for recall bias within this period, beyond a fiveyear timeframe recall bias has been shown to increase significantly (Hassan 2006). Conversely, the majority of surveyed households were not satisfied with local seafood availability.

A declining pattern in local seafood consumption may be explained by interrelated changes taking place in the fishing industry and at the household level. At an industry level, low commercial quotas and declining catch rates for many species, a declining fisheries workforce, and short fishing seasons all potentially impact the availability of local seafood. Short seasons also shorten the time that fresh seafood is available for sale. This outcome was described by Deatra who said, “...[I] used to be able to buy [from the fish plant] whatever's in season. Now you can't. Even I have to ask when crab will close. Last year, I never got any crab because the season was so short." In the longer term, recruitment and retention of workers is a key challenge facing the industry, with implications for the amount of seafood landed in local communities and available for consumption. There are also strong pressures to eliminate many more fish harvesters and more plants in efforts to rationalize the industry (Walsh 2011). This was especially evident in the Memorandum of Understanding (MOU) signed in 2009 by the Newfoundland and Labrador Department of Fisheries and Aquaculture, the Association of Seafood Producers, and the Fish Food and Allied Workers' Union (Clift 2011) that promoted restructuring and rationalizing the industry, in particular through reducing inshore fleets and small processing plants in more rural parts of the province (Walsh 2011). Rationalization of the industry also has implications for subsistence use because limits on the number of enterprises results in a reduction of the number of families directly accessing fish.

In addition to commercial fisheries, many households described more restricted access to fish for subsistence over time. In the 1970s, fishing licenses were introduced in the province and recreational fishing also became more regulated. Edward explained: "Years ago with no regulations on fishing we used to get all kinds of fish. Now we're lucky if we get a bit of codfish... We were used to all this freedom, all of a sudden you can only do what they tell you you can do. Bit inconvenient." Since the collapse of cod fisheries in the 1990s new rules have been introduced around local seafood access and allocations, including the Professionalization Act (Government of Newfoundland and Labrador 1997). Professionalization aims to restrict fish harvesting to those who meet established guidelines and training for full-time harvesters and limit the fisheries part-time harvesters can access (Bavington et al. 2004). Commercial harvesters without some limited entry licenses and the general public cannot access some species, such as snow crab and lobster, for subsistence or sale. The general public can only fish for cod, salmon, and trout by purchasing recreational permits. Sam, a senior who grew up in the region, described increasing restriction to subsistence access of lobster: "You could set out a pot and get a few lobsters for yourself. Then after you had to have a license. Now you can't set a pot, only if you're a bona fide fisherman."

Although changes in the fishing industry are potentially making local seafood harder to access, changes at a household level, including a lack of food skills and increasing constraints on time for preparing food, may also be contributing to less seafood consumption. As fewer young families enter into fishing, the food skills for preserving and preparing seafood are also declining. Some young families described not having the skills to prepare fish and ate less fish for this reason. Michael, who has a wife and young son, said, "A lot of my generation we don't have cooking skills. Don't know what to do with it [fish]." When Michael's family purchased fish it was usually a combination of filleted fish from plants and what he called "breaded stuff" such as fish sticks from supermarkets. Some other families said that not having enough time prevented them from eating more seafood. Debbie, a mother of three, said: "With me and a busy schedule I don't have time, I don't plan. Would love to eat it [fish] more." These changes to diets in Bonne Bay are reflective of a broader "nutrition transition" seen across many developed countries over the past several decades, characterized by declining food skills and eating patterns that include a greater proportion of preprepared foods (Caraher and Coveney 2004, Hawkes 2006, 2007).

This discussion has centered on fisheries around Bonne Bay, and their changing contributions to community food security over time. However, a basic feature of foodscapes is their interconnectedness. Fisheries are a vital part of the Bonne Bay coastal foodscape alongside the interrelated, land-based sources consisting of gardens, berry patches, hunting grounds, and grocery stores. Looking at this combination of ocean and land resources in the coastal foodscape around Bonne Bay is helpful for understanding resilience in the food system. A resilient system is generally understood as one that can persist, adapt, be innovative, and transform, and is prepared to deal with change (Berkes et al. 2002). In the literature on community food security, resilience has mostly been discussed in terms of maintaining diversity and variability in food sources (Feenstra 2002, Stroink and Nelson 2009). Traditionally, diversity in the local food system around Bonne Bay was achieved by households prosecuting a range of food resources, on land and at sea, and providing for themselves as much food as they could (Ommer et al. 2007).

Although reliance on local food resources has declined today compared to the past, the food provisioning strategies of many households remain based on a combination of purchasing and self-provisioning from the land and sea. These different food sources are more or less important at different times of the year. For example, in the winter months when driving long distances to supermarkets is difficult, households tend to rely more on small food stores within the region and on self-provisioned foods they have stored for the winter, including moose meat and salt or frozen fish. Further, representatives of most households in the sample described changes in diets related to the seasonal availability of different local foods. Tina described her family's seasonal transition between eating fish and moose: "Fish once a week because it's summer, and cod we've been having a good bit of that the last three weeks. But through the winter fish maybe once every two weeks, moose meat once a week." A diversity of food sources combining self-provisioning and food purchasing, that to the extent possible are based and controlled locally, may help provide some "slack and flexibility" so that the food system can better withstand change (Berkes et al. 2002:15). Understanding the relationship between land and sea resources in the coastal 
foodscape draws attention to the "complexity of approaches" needed to increase resilience and provide "collective strength" for community food security over time (Stroink and Nelson 2009:26).

\section{CONCLUSION}

Fisheries around Bonne Bay shaped the region's settlement patterns and food systems, and remain important to community food security for many in the region today through contributions to diets, livelihoods, and culture. In this paper I used the foodscape construct as a new way to help analyze the changing socialecological interactions that make up the food system and their changing relationship to community food security over time. Further, by integrating knowledge from the somewhat disparate fields of community food security research with research on fisheries rebuilding and governance, this study responds to the well-recognized need for more interdisciplinary approaches to the complex problems of both food security and fisheries rebuilding (Eriksen 2008, Haapasaari et al. 2012).

However, there are threats to the resilience of this coastal foodscape, including the contributions that local fisheries make to community food security. A thrust toward rationalization of the Newfoundland and Labrador and other fisheries and the management of fish stocks and resources for global export production has dominated much of the policy agenda in Eastern Canada and elsewhere over the past 20 years. Within this agenda, fisheries policy tends to treat seafood as a commodity versus as food (Nelson et al. 2013). Likewise, many food policy documents do not consider fisheries to be part of the Canadian food system (Lowitt et al. 2013). The findings of this study support the need for policy retooling that recognizes fisheries as parts of integrated food systems and for policies that support the linkages among fisheries, food, and community well-being (Nelson et al. 2013). However, democratic participation in these decision-making processes is crucial for making food, including fisheries-based systems, responsive to the needs of local citizens (Hassanein 2003). Accompanying the development of interest in community food security are growing political and legal debates around the "right to food" and "food sovereignty" (Anderson 2008, Chilton and Rose 2009, Wittman et al. 2010). What these trends have in common is their emphasis on community capacity to make decisions about food policy and practice as central to food security over the long term.

Responses to this article can be read online at: http://www.ecologyandsociety.org/issues/responses. $\mathrm{php} / 6498$

\section{Acknowledgments:}

This research was supported by the Social Sciences and Humanities Research Council, Memorial University, and the Research and Development Corporation of Newfoundland and Labrador, with additional financial and in-kind support from numerous community partners and groups. The author also acknowledges funding support from the Rural Secretariat, Government of Newfoundland and Labrador; and the MITACS-Accelerate program. The author acknowledges previous publication of some of the results drawn on in this paper in Lowitt, K. 2013. Examining fisheries contributions to community food security: Findings from a household seafood consumption survey on the west coast of Newfoundland. Journal of Hunger and Environmental Nutrition 8(2).

\section{LITERATURE CITED}

Adema, P. 2009. Garlic capital of the world: Gilroy, garlic and the making of a festive foodscape. University Press of Mississippi, Jackson, Mississippi, USA. http://dx.doi.org/10.14325/ mississippi/9781604731200.001.0001

Allen, P. 2010. Realizing justice in local food systems. Cambridge Journal of Regions, Economy, and Society 3(2):295-308. http://dx. doi.org/10.1093/cjres/rsq015

Anderson, M. D. 2008. Rights-based food systems and the goals of food systems reform. Agriculture and Human Values 25 (4):593-608. http://dx.doi.org/10.1007/s10460-008-9151-z

Anderson, M. D., and J. T. Cook. 1999. Community food security: practice in need of theory? Agriculture and Human Values 16:141-150. http://dx.doi.org/10.1023/A:1007580809588

Appadurai, A. 1990. Disjuncture and difference in the global economy. Theory, Culture \& Society 7:295-310. http://dx.doi. org/10.1177/026327690007002017

Bavington, D., B. Gretzic, and B. Neis. 2004. The feminist political ecology of fishing down: reflections from Newfoundland and Labrador. Studies in Political Economy 73:159-182.

Berkes, F. 2011. Restoring unity: the concept of marine socialecological systems. Pages 9-28 in R. E. Ommer, R. I. Perry, K. Cochrane, and P. Cury, editors. World fisheries: a social-ecological analysis. Blackwell Publishing, Oxford, UK. http://dx.doi. org/10.1002/9781444392241.ch2

Berkes, F., J. Colding, and C. Folke, editors. 2002. Navigating social-ecology systems: building resilience for complexity and change. Cambridge University Press, New York, New York, USA. http://dx.doi.org/10.1017/CBO9780511541957

Caraher, M., and J. Coveney. 2004. Public health nutrition and food policy. Public Health Nutrition 7(5): 591-598. http://dx.doi. org/10.1079/PHN2003575

Carlsson, L., and P. L. Williams. 2008. New approaches to the health promoting school: participation in sustainable food systems. Journal of Hunger and Environmental Nutrition 3 (4):400-417. http://dx.doi.org/10.1080/19320240802529243

Charles, A. 2011. Good practices for governance of small-scale fisheries. Pages 285-298 in R. Chuenpagdee, editor. World smallscale fisheries: contemporary visions. Eburon Academic, Delft, The Netherlands.

Chase, S. 2003. Closing the North American mixed-stock commercial fishery for wild Atlantic salmon. Pages 84-92 in D. Mills, editor. Salmon at the edge. Blackwell Science, Oxford, UK. http://dx.doi.org/10.1002/9780470995495.ch8

Chilton, M., and D. Rose. 2009. A rights-based approach to food insecurity in the United States. American Journal of Public Health 99(7):1203-1211. http://dx.doi.org/10.2105/AJPH.2007.130229 
Clift, T. 2011. Report of the independent chair: MOU steering committee on fishing industry rationalization and restructuring. Newfoundland and Labrador Fishing Industry Rationalization and Restructuring. Department of Fisheries and Aquaculture, St. John's, Newfoundland and Labrador, Canada. [online] URL: http://www.fishaq.gov.nl.ca/publications/mou.pdf

Coulthard, S. 2012. Can we be both resilient and well, and what choices do people have? Incorporating agency into the resilience debate from a fisheries perspective. Ecology and Society 17(1): 4. [online] URL: http://www.ecologyandsociety.org/vol17/iss 1/art4/ http://dx.doi.org/10.5751/ES-04483-170104

Cummins, S., and S. Macintyre. 2002. A systematic study of an urban foodscape: the price and availability of food in greater Glasgow. Urban Studies 39(11):2115-2130. http://dx.doi. org/10.1080/0042098022000011399

Dietitians of Canada. 2007. Community food security: position of dietitians of Canada. Dietitians of Canada, Toronto, Ontario, Canada. [online] URL: http://www.dietitians.ca/DownloadableContent/Public/cfs-position-paper.aspx

Eriksen, P. J. 2008. What is the vulnerability of a food system to global environmental change? Ecology and Society 13(2): 14. [online] URL: http://www.ecologyandsociety.org/vol13/iss2/ $\underline{\operatorname{art} 14 /}$

Feagan, R. 2007. The place of food: mapping out the 'local' in local food systems. Progress in Human Geography 31(1): 23-42. http://dx.doi.org/10.1177/0309132507073527

Feenstra, G. 2002. Creating space for sustainable food systems: lessons from the field. Agriculture and Human Values 19 (2):99-106. http://dx.doi.org/10.1023/A:1016095421310

Fisheries and Oceans Canada. 1997. Atlantic salmon: Newfoundland and Labrador, salmon fishing areas 1-14B. Science Branch, Fisheries and Oceans Canada, St. John's, Newfoundland and Labrador, Canada.

Fisheries Resource Conservation Council (FRCC). 2011. Towards recovered and sustainable groundfish fisheries in Atlantic Canada: a report to the Minister of Fisheries and Oceans. Fisheries Resource Conservation Council, Ottawa, Ontario, Canada.

Food and Agriculture Organization (FAO). 2005. Increasing the contribution of small-scale fisheries to poverty alleviation and food security. FAO, Rome, Italy.

Food and Agriculture Organization (FAO). 2012. The state of world fisheries and aqauculture 2012. FAO, Rome, Italy.

Friedberg, S. 2010. Perspective and power in the ethical foodscape. Environment and Planning A 42:1868-1874. http://dx.doi. org/10.1068/a43217

Geller, P. L. 2009. Bodyscapes, biology and heteronormativity. American Anthropologist 111(4):504-516. http://dx.doi.org/10.1111/ j.1548-1433.2009.01159.x

Government of Newfoundland and Labrador. 1990. Fish Inspection Act. Government of Newfoundland and Labrador, St. John's, Newfoundland and Labrador, Canada.

Government of Newfoundland and Labrador. 1997. Professional Fish Harvesters Act. Government of Newfoundland and Labrador, St. John's, Newfoundland and Labrador, Canada.
Haapasaari, P., S. Kulmala, and S. Kuikka. 2012. Growing into interdisciplinarity: how to converge biology, economics, and social science in fisheries research? Ecology and Society 17(1): 6. [online] URL: http://www.ecologyandsociety.org/vol17/iss1/art6/

Hamm, M. W., and A. C. Bellows. 2003. Community food security and nutrition educators. Journal of Nutrition Education and Behavior 35:37-43. http://dx.doi.org/10.1016/S1499-4046(06) $\underline{60325-4}$

Hanazaki, N., F. Berkes, C. S. Seixas, and N. Peroni. 2013. Livelihood diversity, food security and resilience among the Caiçara of coastal Brazil. Human Ecology 41:153-164. http://dx. doi.org/10.1007/s10745-012-9553-9

Hanrahan, M. 2002. A veritable scoff. Flanker, St. John's, Newfoundland and Labrador, Canada.

Hassan, E. 2006. Recall bias can be a threat to retrospective and prospective research designs. Journal of Epidemiology 3(2):4.

Hassanein, N. 2003. Practicing food democracy: a pragmatic politics of transformation. Journal of Rural Studies 19(1):77-86. http://dx.doi.org/10.1016/S0743-0167(02)00041-4

Hauzer, M., P. Dearden, and G. Murray. 2013. The fisherwomen of Ngazidja island, Comoros: fisheries livelihoods, impacts, and implications for management. Fisheries Research 140:28-35. http://dx.doi.org/10.1016/j.fishres.2012.12.001

Hawkes, C. 2006. Uneven dietary development: linking the policies and processes of globalization with the nutrition transition, obesity and diet-related chronic diseases. Globalization and Health 2(4).

Hawkes, C. 2007. Promoting healthy diets and tackling obesity and diet-related chronic diseases: What are the agricultural policy levers? Food and Nutrition Bulletin 28(2 supplement):S312-321.

Hilborn, R., I. J. Stewart, T. A. Branch, and O. P. Jensen. 2012. Defining trade-offs among conservation, profitability, and food security in the California current bottom-trawl fishery. Conservation Biology 26(2):257-268. http://dx.doi.org/10.1111/ j.1523-1739.2011.01800.x

Hinrichs, C. C. 2003. The practice and politics of food system localization. Journal of Rural Studies 19(1):33-45. http://dx.doi. org/10.1016/S0743-0167(02)00040-2

Ingold, T. 1993. The temporality of the landscape. World Archaeology 25(2):152-174. http://dx.doi.org/10.1080/00438243.$\underline{1993.9980235}$

Johnston, J., A. Biro, and N. MacKendrick. 2009. Lost in the supermarket: the corporate-organic foodscape and the struggle for food democracy. Antipode 41:509-532. http://dx.doi. org/10.1111/j.1467-8330.2009.00685.x

Khan, A. 2011. Is rebuilding collapsed fisheries a wicked problem? Lessons from a fish chain analysis of Northern Gulf cod fisheries. Dissertation. Memorial University of Newfoundland, St. John's, Newfoundland and Labrador, Canada.

Khan, A. S., and B. Neis. 2010. The rebuilding imperative in fisheries: clumsy solutions for a wicked problem? Progress in Oceanography 87:347-356. http://dx.doi.org/10.1016/j.pocean.2010.09.012 
Kloppenburg, J. Jr., J. Hendrickson, and G. W. Stevenson. 1996. Coming in to the foodshed. Agriculture and Human Values 13 (3):33-42. http://dx.doi.org/10.1007/BF01538225

Kuzel, A. 1992. Sampling in qualitative inquiry. Pages 31-44 in B. Crabtree and W. Miller, editors. Doing qualitative research. Sage, London, UK.

Levkoe, C. Z., and S. Wakefield. 2011. The community food centre: creating space for a just, sustainable, and healthy food system. Journal of Agriculture, Food Systems, and Community Development 2(1):249-268. http://dx.doi.org/10.5304/jafscd.2011.021.012

Loring, P. A., and S. C. Gerlach. 2009. Food, culture, and human health in Alaska: an integrative health approach to food security. Environmental Science and Policy 12(4):466-478. http://dx.doi. org/10.1016/j.envsci.2008.10.006

Loring, P. A., S. C. Gerlach, and H. L. Harrison. 2013. Seafood as local food: food security and locally caught seafood on Alaska's Kenai Peninsula. Journal of Agriculture, Food Systems, and Community Development 3(3):13-41. http://dx.doi.org/10.5304/ jafscd.2013.033.006

Lowitt, K. 2012. The reinvention and performance of traditional Newfoundland foodways in culinary tourism in the Bonne Bay region. Newfoundland and Labrador Studies 27(1):63-78.

Lowitt, K. 2013. Examining fisheries contributions to community food security: findings from a household seafood consumption survey on the west coast of Newfoundland. Journal of Hunger and Environmental Nutrition 8(2):221-241. http://dx.doi. org/10.1080/19320248.2013.786668

Lowitt, K., M. Nagy, C. Nelson, and D. Bavington. 2013. Where's the fish? Alternatives Journal 39(4):24-28.

MacDonald, M., P. Sinclair, and D. Walsh. 2013. Globalization, fisheries and recovery. Community-University Research for Recovery Alliance, Memorial University of Newfoundland, St. John's, Newfoundland and Labrador, Canada.

Manning, E. 2009. Relationscapes: movement, art, philosophy. MIT Press, Cambridge, Massachusetts, USA. http://dx.doi. org $/ 10.7551 / \mathrm{mitpress} / 9780262134903.001 .0001$

Mannion, J. 1977. Settlers and traders in western Newfoundland. Pages 234-275 in J. Mannion, editor. The peopling of Newfoundland. ISER Books, St. John's, Newfoundland and Labrador, Canada.

Marshall, N., and P. Marshall. 2007. Conceptualizing and operationalizing social resilience within commercial fisheries in northern Australia. Ecology and Society 12(1): 1. [online] URL: http://www.ecologyandsociety.org/vol12/iss1/art1/

McClanahan, T., E. H. Allison, and J. E. Cinner. 2013. Managing fisheries for human and food security. Fish and Fisheries. http:// dx.doi.org/10.1111/faf.12045

Mikkelsen, B. E. 2011. Images of foodscapes: introduction to foodscape studies and their application in the study of healthy eating out-of-home environments. Perspectives in Public Health 131(5):209-216. http://dx.doi.org/10.1177/1757913911415150

Mitchell, D. 2001. The lure of the local: landscape studies at the end of a troubled century. Progress in Human Geography 25 (2):269-281. http://dx.doi.org/10.1191/030913201678580520
Moerlein, K. J., and C. Carothers. 2012. Total environment of change: impacts of climate change and social transitions on subsistence fisheries in northwest Alaska. Ecology and Society 17 (1): 10. http://dx.doi.org/10.5751/ES-04543-170110

Murphy, I., and B. Neis. 2011. Navigating the legislative requirements for fisheries-tourism initiatives in Newfoundland and Labrador. Community-University Research for Recovery Alliance, Memorial University of Newfoundland, St. John's, Newfoundland and Labrador, Canada.

Nelson, C., K. Lowitt, M. Nagy, and D. Bavington. 2013. Research commentary: future research approaches to encourage small-scale fisheries in the local food movement. Journal of Agriculture Food Systems and Community Development 3 (4):177-181.

Newfoundland and Labrador Statistics Agency. 2009. Community Accounts. Department of Finance, Government of Newfoundland and Labrador, St. John's, Newfoundland and Labrador, Canada. [online] URL: http://nl.communityaccounts. ca/default.asp

O'Dell, T., and P. Billing, editors. 2005. Experiencescapes: tourism, culture, and economy. Copenhagen Business School Press, Herndon, Virginia, USA.

Ommer, R., and the Coasts Under Stress Research Team. 2007. Coasts under stress: restructuring and social-ecological health. McGill-Queen's University Press, Kingston, Ontario, Canada.

Ommer, R., N. Turner, M. MacDonald, and P. Sinclair. 2007. Food security and the informal economy. Pages 115-128 in C. Parrish, N. Turner, and S. Solberg, editors. Resetting the kitchen table: food security, culture, health and resilience in coastal communities. . Nova Science, New York, New York, USA.

Omohundro, J. 1994. Rough food: the seasons of subsistence in Northern Newfoundland. ISER Books, St. John's, Newfoundland and Labrador, Canada.

Parrish, C., N. Turner, and S. Solberg, editors. 2008. Resetting the kitchen table: food security, culture, health and resilience in coastal communities. Nova Science, New York, New York, USA.

Rose, G. A. 2003. Fisheries resources and science in Newfoundland and Labrador: an independent review. Prepared for the Royal commission on renewing and strengthening our place in Canada. Government of Newfoundland and Labrador, St. John's, Newfoundland and Labrador, Canada. [online] URL: http:// www.gov.nl.ca/publicat/royalcomm/research/Rose.pdf

Stroink, M. L., and C. H. Nelson. 2009. Aboriginal health learning in the forest and cultivated gardens: building a nutritious and sustainable food system. Journal of Agromedicine 14 (2):263-269. http://dx.doi.org/10.1080/10599240902739737

Stroink, M. L., and C. H. Nelson. 2013. Complexity and food hubs: five case studies from Northern Ontario. Local Environment 18(5):620-635. http://dx.doi.org/10.1080/13549839.2013.798635

Walsh, D. 2011. What restructuring? Who's rationalization? Newfoundland and Labrador's Memorandum of Understanding on its fishing industry. Pages 81-100 in R. Chuenpagdee, editor. Contemporary visions for world small-scale fisheries. Eburon Academic, Delft, the Netherlands. 
Winne, M. 2005. Community food security: promoting food security and building healthy food systems. Community Food Security Coalition, Venice, California, USA.

Wittman, H., A. Desmarais, and N. Wiebe. 2010. Food sovereignty: reconnecting food, nature and community. Fernwood, Halifax, Nova Scotia, Canada. 